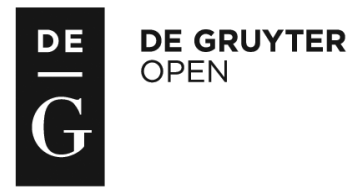

Administration, vol. 65, no. 2 (2017), pp. 127-144

doi: 10.1515/admin-2017-0018

\title{
Lobbying regulation in Ireland: Fool's errand or finest hour?
}

\author{
Gary Murphy \\ Dublin City University
}

\begin{abstract}
This paper examines and assesses the strengths and weaknesses of the 2015 Regulation of Lobbying Act passed by the Fine Gael/Labour government. It addresses the question of whether the Act was of a cosmetic nature with little impact on openness, transparency and accountability in public life or whether it was the result of positive policy learning from international experiences. After assessing the strengths and weaknesses of the Act, the paper argues that the leadership of the Minister for Public Expenditure and Reform, Brendan Howlin, TD, acting in a policy entrepreneurial way, was vital to the implementation of the Act in its final form. Finally, the paper advocates the view that the introduction of this Act is of crucial importance in ensuring that public policymaking in the Irish state is open, transparent and accountable.
\end{abstract}

Keywords: Lobbying, regulation, accountability, political leadership, citizens

\section{Introduction}

On 20 June 2014 the Minister for Public Expenditure and Reform, Brendan Howlin, TD, published the Registration of Lobbying Bill, 2014. Declaring that the purpose of the bill was to establish a webbased register of lobbying activity and deliver appropriate transparency on 'who is contacting whom about what', Minister Howlin stated that lobbying had a very important role to play in 
helping to ensure all perspectives, assessments and opinions are presented and available to inform decision-making in key areas of public policy and legislative proposals. In that context, he asserted that the publication of the bill marked an important step in the process of helping to 'rebuild public trust in the political system by throwing light on its interaction with those who seek to shape and influence policy across all sections of society' (Department of Public Expenditure and Reform, 2014). Coming over three years into the Fine Gael/Labour coalition's term of office, the bill was part of a package of reform measures which the government, on its formation, hoped would not only ensure clean politics in Ireland but also restore public trust in politics and the political class after the trauma of the financial crash and the troika bailout, which resulted in the collapse of the Fianna Fáil/Green Party government in early 2011 (Murphy, 2016, p. 153).

The election of 2011 could well be considered the 'Ireland has failed' election in that the question of how a stable representative democracy lost its economic sovereignty and its ability to make decisions for itself had to be addressed and answered. Political reform was thus central to that election, with all major political parties outlining significant proposals on how to cure the country's political ills. Central to these proposals was the regulation of lobbyists. In that context this paper assesses the Fine Gael/Labour government's Regulation of Lobbying Act, 2015, and examines the role it has played in terms of transparency and accountability in Irish politics. It places the Act in an international context and assesses its strengths and weaknesses when compared with similar regulatory systems across the globe. Finally, it answers the question of whether the regulation of lobbyists was the finest hour of the Fine Gael/Labour government's record in relation to their reform agenda, or whether it was nothing but a fool's errand which has done little more than ensure lobbyists place themselves on a register, and concomitantly shines no real light on transparency in Irish public life.

\section{Regulation of Lobbying Act, 2015}

Internationally, the regulation of lobbying has been rather random and haphazard. In 1946 the US became the first country to introduce lobbying regulation covering its federal government. It was followed by Germany (1951), Canada (1989), the European Parliament (1996), Poland (2005), Hungary (2006), Israel (2008), France (2009), Mexico (2010), Slovenia (2010), Austria (2012), Italy (2012), Netherlands 
(2012), Chile (2014) and Great Britain (2014). Australia introduced rules in 1983, abandoned them in 1996 and reintroduced them again in 2008. As a recent study has pointed out, there has been a significant lack of transparency around the public affairs and lobbying industry, which has been caused by the 'absence of any regulation in the field in most countries or by inefficient, flawed and very partial regulations in the countries which made steps ahead in this direction' (Bitonti \& Harris, 2017, pp. 7-8). It is widely acknowledged that 'schemes to regulate lobbying derive from concerns over the democratic deficit, the openness and transparency of government, equality of access to public affairs, and the perceived need to manage information flows to and from governments' (Chari et al., 2007, p. 422). There is no perfect model for regulating lobbying. Different types of democratic systems, rules, habits and norms produce different types of lobbying. In that context regulation cannot be conceived as something simply to be applied in the same terms across the globe. Different countries have different loopholes and limits within their regulatory frameworks, making it impossible to have a one-size-fits-all global model of lobbying regulation (Bitonti \& Harris, 2017, p. 11). Nevertheless, various governments across the globe have been giving increasing thought to the concept of regulating lobbying and it is within this context that we can place the Irish government's 2015 Regulation of Lobbying Act. Successive Irish governments dating back to the Fianna Fáil/Progressive Democrats (PD) coalition of 2002-7 have examined the global regulation of lobbying at both local and national levels. Thus, promises to introduce lobbying legislation in Ireland are based upon the assessment of how regulation of lobbying has taken place elsewhere, but in the knowledge that such regulations cannot be simply or even easily replicated.

As part of its commitment to ushering in a new era in Irish politics the Fine Gael/Labour government, in a section titled 'We Will Overhaul the Way Politics and Government Works' in its programme for government, promised to introduce a statutory register of lobbyists, and rules concerning the practice of lobbying' (Department of the Taoiseach, 2011, p. 20). The regulation of lobbyists basically promotes the idea that political systems have established rules which lobby groups must follow when trying to influence government officials and office holders. Moreover, in robust legislative systems this cannot be a matter of lobbyists voluntarily complying. Rather, regulations must be codified and formal rules must be passed by government and written into law that is then enforced and must be 
respected. Non-compliance should result in penalisation through either fines or imprisonment.

In that context, in the lobbying bill of 2014 lobbyists - the 'who' were defined as employers or their staff (where the employer has more than ten employees), third-party lobbyists (those who are paid by a client to lobby on clients' behalf) or anyone lobbying about the zoning of land. The lobbied - the 'whom' - were referred to as designated public officials and were defined as ministers and ministers of state, members of Dáil Éireann and Seanad Éireann, members of the European Parliament for constituencies in the state, members of local authorities, special advisers and senior civil servants. The matters about which lobbyists are communicating with the lobbied - the 'what' - were defined as communications about the initiation, development or modification of any public policy or programme, the preparation of legislation, and the award of any grant, loan or contract (Murphy, 2017, p. 203).

The key point for Minister Howlin and the Department of Public Expenditure and Reform, which drove the scheme, was to strengthen the degree of openness and scope for public scrutiny of the interactions and engagements between all sectors of society and the political and administrative systems of the state. In that context, the idea of the legislation was to allow the public to 'reach informed, evidence-based judgements about the extent to which different interest groups are accessing key decision makers across the political and public service systems and would be expected to increase the public understanding of lobbying activity in Ireland' (Murphy, 2017).

Nine months after the publication of the bill, on 11 March 2015, the Regulation of Lobbying Act was signed into law with the government stating that the purpose of the Act was to provide for a web-based register of lobbying to make information available to the public on 'the identity of those communicating with designated public officials on specific policy, legislative matters or prospective decisions' (Standards in Public Office Commission, 2015). The distinction in the year between the Registration of Lobbying Bill and the Regulation of Lobbying Act is an important one. In April 2013 the Department of Public Expenditure and Reform published a General Scheme of the Regulation of Lobbying Bill to interested parties, and invited comments from same. The publication of the Registration of Lobbying Bill the following year suggested that the purpose of the original bill had been significantly weakened. This is not simply a matter of semantics. A register of lobbying, with its implication of just being a 
list of lobbyists, raised significant doubts as to the government's seriousness about its own Act. An Act titled along the lines of Regulation of Lobbying implied a far more substantive piece of legislation, encompassing how the very act of lobbying would be regulated by those who actually registered as lobbyists. When the government finally signed the bill into law in 2015, it reverted to using the wording 'Regulation of Lobbying' as the title of the Act. This reversion to the original wording in the general scheme is important, as it makes clear that the government reverted back to its original intention and ambition in ensuring that it was actually introducing a regulatory framework for lobbyists, and was not simply establishing a registration scheme. This reversion to the original title and ambition was brought about by Minister Howlin and his officials when he was advised that governments who brought in lobbying legislation commonly used the wording 'regulation of lobbying' rather than 'register of lobbying', as the latter simply denoted a list while the former clearly articulated a much more comprehensive framework within which individual governments viewed lobbying activities within their own states. As this is how the Fine Gael/Labour government intended their own bill to work, the title reverted to the more substantive 'Regulation of Lobbying'. ${ }^{1}$

The leadership of Minister Howlin was crucial in this regard. Minister Howlin clearly wanted the legislation passed in the first place, and then for it to work. In that context he acted as a political policy entrepreneur. ${ }^{2} \mathrm{He}$ had faced various complaints from numerous organisations and lobbying groups that any legislation which actually regulated how lobbyists did their business with government would be simply unworkable, and that a register would be simpler and more effective. But Minister Howlin was cognisant of the fact that a register of lobbyists would be pretty pointless if it simply listed lobbyists and provided minimalist information as to who they met. Instead, his entrepreneurial approach to public policy ensured that the public would have information on who the lobbyists were, who they lobbied and what they lobbied about. It was he who signed off the more expansive and accurate title of 'Regulation of Lobbying' as it more

1 The current author, Dr Raj Chari of Trinity College Dublin and Dr John Hogan of Dublin Institute of Technology acted as pro bono advisors to the Department of Public Expenditure and Reform during the drafting of the bill. I am grateful to them both for their insights on the Regulation of Lobbying Act.

${ }^{2}$ On the role of political entrepreneurs, see Hogan \& Feeney (2012). 
accurately reflected what the Act was about. Both title and Act benefited from Minister Howlin's leadership.

An important part of the Act is that it provides restrictions and conditions on the taking up of a variety of employments by certain designated officials and public office holders for a specified period of time where a possible conflict of interest arises; the so-called coolingoff period (Chari et al., 2010, p. 4). Later in 2015, the online register www.lobbying.ie was launched and a Head of Lobbying Regulation was appointed. After an international competition, Sherry Perreault, formerly a senior director with Canada's Office of the Conflict of Interest and Ethics Commissioner was appointed Ireland's first Head of Lobbying Regulation. A sixteen-person advisory group, chaired by the Head of Lobbying Regulation, and consisting mainly of representatives of groups impacted by the Act, was appointed to provide information and guidance to the Standards in Public Office Commission, under whose auspices the lobbying regulator works, and to assist in addressing various implementation issues arising from the establishment of the lobbying register. With the introduction of the Regulation of Lobbying Act, Ireland became the sixteenth democracy in the world to introduce such legislation aimed at ensuring that citizens have the right to know who is lobbying their government, its officials and officeholders, and what they are lobbying them about.

\section{Regulating lobbying: A long gestation}

Since independence in 1922, Ireland has theoretically had a history of open government that has encouraged participative debate with its citizens. The reality has been somewhat different. The dark underbelly of lobbying in Ireland was laid bare as the intersection between the policymaking process and those who wanted to influence it was openly revealed in a number of tribunals of inquiry investigating payments to politicians. At their heart, these tribunals manifestly showed that the Irish policymaking process was neither open nor transparent, and was open to corruption (Byrne, 2012). In that context the activities of individuals or groups attempting to influence national and local politicians, as well as public officials, came under particular scrutiny. It was this perception of corrupt influence that the Fine Gael/Labour government of 2011-16 was attempting to address with its 2015 Lobbying Act.

Yet this particular Act had an extremely long gestation. Irish political parties had been actively considering the issue of regulating 
lobbyists since the end of the twentieth century. Beginning in 1999, the Labour Party introduced no less than four private members' bills on this issue. None reached the statute book as the Fianna Fáil/PDs coalition government, which dominated Irish politics in the decade between 1997 and 2007, showed little interest in the issue. Lobbying regulation did at one stage cross the radar of the PDs. In 2003 the then Minister for Justice, Equality and Law Reform, Michael McDowell, $\mathrm{TD}$, forcefully noted that a major positive consequence of lobbying regulation should be that 'professional ethical lobbyists' take the place of 'fly-by-night secretive intermediaries with dubious motives and ethics' (McGrath, 2009, p. 269). This can best be interpreted as a shot across the bows of his Fianna Fáil partners, coming on the back of the PDs' surprisingly good result in the 2002 election, which saw them come back to power with Fianna Fáil. Yet in 2007, prior to that year's general election, McDowell was telling the Dáil, as Tánaiste, 'that it is not intended at this stage to introduce lobbyists' registration legislation' (McGrath, 2009, p. 265). This was at a time when concern about Taoiseach Bertie Ahern's finances was at its highest and when the tribunals of inquiry into payments to politicians and land rezoning in Dublin, which had uncovered numerous examples of undue influence by lobbyists of one sort or other, had been in progress for ten full years. McDowell ultimately took the view that tribunals of inquiry should be left to finish their work before any other legislation dealing with undue influence in Irish politics was introduced.

In 2007 Bertie Ahern proved himself to be the great survivor of Irish politics, winning his third general election in a row, and he subsequently formed a government with the Green Party and the PDs. The Greens were far more convinced than Fianna Fáil or the PDs of the need for lobbying regulation in Irish public life and, in the negotiations for government, insisted on such legislation as part of their participation in government. Fianna Fáil readily conceded this to the Greens, but in the most piecemeal of fashions by agreeing in its last page of the programme for government to 'consider legislation to regulate lobbyists' (Department of the Taoiseach, 2007, p. 87).

However, when the programme for government was renewed in late 2009, after the calamitous economic crash, the pledge became far more concrete: 'we will introduce a Register of Lobbyists, including professional, corporate and NGO' (Department of the Taoiseach, 2009, 33). By the time this government fell, in January 2011, no such legislation had been introduced. During this time the main opposition parties Fine Gael and Labour were developing proposals relating to 
lobbying regulation. In March 2010 Fine Gael published a comprehensive political reform plan entitled New Politics, where they advocated the view that political reform was central to the economic recovery of the state. While the main headline act of the Fine Gael plan was the proposal to abolish the Seanad (MacCarthaigh \& Martin, 2015), Fine Gael also pledged to reduce the numbers of TDs in the Dáil by twenty, strengthen the Dáil committee system, give a vote in presidential elections to Irish citizens living abroad and introduce an Open Government Bill, which would significantly strengthen freedom of information, register all lobbyists and protect whistle-blowers. It provided specific details on how lobbying would be regulated under a government led by Fine Gael (Murphy et al., 2011, p. 115). By the time the Fine Gael/Labour government of 2011-16 ended in February 2016 only half of these aims had been achieved and the government's Seanad abolition referendum had been defeated.

For its part, Labour published proposals in November 2010 setting out a wide range of reform measures, including measures on Dáil reform, cabinet confidentiality, freedom of information, whistleblowers' legislation, political contributions, electoral spending limits and the regulation of lobbyists. With both Fine Gael and Labour committed to introducing such legislation, the way was clear for them to do so after their decisive victory in the February 2011 general election.

\section{Lobbying, transparency and accountability}

The new government enshrined in its programme for government its intention to introduce lobbying regulation and a statutory register of lobbyists. While it took over four years, this promise was fulfilled in 2015 with the publication and passing of the Regulation of Lobbying Act. This leads us to the question of whether this Act will actually succeed in its stated aim of delivering appropriate transparency on 'who is contacting whom about what'. There is a convincingly large literature on the themes of transparency, accountability and lobbying, which has contributed greatly to our understanding of the global importance of citizens being reassured by transparent politics in their respective polities.

In relation to lobbying specifically, both Lagerlof \& Frisell (2004, p. 16) and Chari et al. (2010) contend that making lobbyists register as part of a wider regulatory framework helps promote transparency. In that context lobbying regulations are thus justified in order to render 
government officials more accountable and promote the transparency of lobbyists' actions. Moreover, by imposing an obligation on lobbyists to disclose the identity of those on whose behalf they are acting, governments are essentially making laws that take account of the public interest (Graziano, 2001, p. 99). As Thomas (2004, p. 287) notes, such rules 'constrain the actions of lobbyists and public officials alike, even if they do not ultimately affect which groups are powerful and which ones are not'. Through contributing to transparency and accountability, lobbying regulations shed light into policymaking, and in so doing should unquestionably improve the overall nature of decisions made by governments (Dryzek, 2000; Elster, 1998; Keohane \& Nye, 2003). If citizens know who are lobbying governments, and the nature of the lobbying, then it is reasonable to assume that those governments will take decisions that are in the public interest as distinct from private interests. Transparency and accountability are the key elements in this regard. As long as governments are open about who has lobbied them, then it makes sense that they can robustly defend their public policies, safe in the knowledge that there is no secrecy about what might have influenced any specific decision.

Where stands Ireland in this theoretical lobbying framework which promotes transparency and accountability? Two levels of lobbying of parliament are apparent in the Irish state. One seeks to influence national policy; the other, local or constituency issues. While members of parliament are lobbied by the full range of interest groups, the ongoing clientelist nature of the Irish state means they are most sensitive to representations that have a constituency dimension, either because these concern a local issue or a national issue with a local aspect, or are simply so emotive, such as the downgrading of hospital services, that they can affect the electoral preferences of a significant number of voters. As Minister Howlin noted in launching the Irish lobbying register: 'lobbying is absolutely necessary in order to maintain a healthy and well-functioning democracy. Neither Government nor the public service has a monopoly on wisdom. We cannot operate in a vacuum. We need to hear the perspectives of all sectors in order to make sound well informed decisions which best serve the needs of society as a whole' (Howlin, 2015).

Interest groups play a central role in Irish society by theoretically acting as a conduit between citizens and the government (Murphy, 2010a, p. 327). Interest groups, however, are much more than simple conduits and lobby in the expectation that they will receive some real and tangible benefits for their efforts. In that context the access and 
expectation such groups have in relation to Irish policymakers can be of great significance for policy outcomes in the Irish state (Fallon, 2011; Murphy, 2010b). Interest group activity in Ireland spans numerous strands and can be identified on three levels: social partnership, where sectional groups, such as trade unions, employers and farmers' interests, had central roles in the economic governance of the state between 1987 and 2009; cause advocacy, where groups attempt to influence policy outcomes in specific areas such as the environment or on questions of morality such as abortion, divorce and same-sex marriage; and private lobbying, where a feature of policymaking in Ireland in recent years has been the increasingly vigorous lobbying on behalf of business or private interests in an attempt to influence specific government policy (Murphy \& McGrath, 2011, p. 71).

Interest groups pursue their goals through a number of different channels. These include public and private pressure on government, individual politicians and other interest groups, and the use of the mass media, including a number of increasingly influential instantaccess news media websites. Yet despite all the other avenues open to interest groups, it is still the Dáil and its members who remain the prime focus for such lobbying, principally because parliament is the centre for information, access and publicity for such groups. It remains Ireland's charmed circle of power. TDs have access to insider information, can generate publicity - particularly given the televising of Dáil proceedings, and the opportunity this provides for showmanship - and are in a position to put pressure on governments and individual ministers by tabling parliamentary questions.

\section{The balance sheet assessed}

In that context the question we need to ask is to what extent does the Regulation of Lobbying Act contribute to making Irish government in all its forms more open, transparent and accountable? The Regulation of Lobbying Act contains many significant benefits that will clearly be of value in promoting transparency in Irish public life. Primarily, and most importantly, it is at its heart a statutory register covering the full spectrum of the lobbying industry. It has clear definitions of what lobbying, including grassroots lobbying, involves and of which policymakers and policy issues are involved. Moreover, the register is freely available for the public to consult on the Internet and in turn is easy for lobbyists to use, as they are able to file their returns 
electronically. Furthermore, the Act gives clear rules on the information which lobbyists must disclose on the register and it has appropriate provision for delayed publication of information in specified circumstances only. Crucially, the establishment of an Office of Lobbying Regulation within the Standards in Public Office Commission, which is independent of both government and industry and led by an experienced professional with wide international experience, provides significant comfort that the Act will be thoroughly enforced. The fact that the Head of Lobbying Regulation has clearly delineated functions and responsibilities should ensure that there is no confusion between the regulators and the lobbyists. This will be helped by the fact that there will be regular reviews of the system and reporting by both the Head of Lobbying Regulation and the Minister for Public Expenditure and Reform to the public and the Oireachtas.

All regulators need teeth and in that context the Act grants appropriate powers for the Standards in Public Office Commission to conduct investigations if it believes that a person has committed or may be committing a relevant contravention of the Act. The penalty for such contravention is also important. There is no point in having a regulator unless they have the resources to bring to book those who either ignore the Act or willfully disobey it. Thus, the range of penalties must be of such magnitude so as to persuade lobbyists not to risk breaking the law. This is the case with the Act, which has administrative and criminal penalties of a fine and potential term of imprisonment of up to two years. ${ }^{3}$ While these may seem somewhat draconian, they are in fact similar in nature to the penalties in use in other democracies with lobbying regulations, and are a vital part of signalling the intent of the government to take the lobbying Act seriously. Moreover, the Head of Lobbying Regulation has made it clear that while the Act must have penalties, she is far more interested in getting lobbyists to comply with the legislation through advocacy and education rather than by penalising them. ${ }^{4}$ In that context the Act performs the vital function of raising awareness of the importance of the independent office of the Head of Lobbying Regulation in promoting both public confidence in the system and compliance by lobbyists. This approach certainly seems to be working. There were over 1,100 registrants and close to 1,500 returns by the close of the first

3 The enforcement procedures for the Act can be seen at http://www.per.gov.ie/wpcontent/uploads/Regulation-of-Lobbying-Act-Part-4-Enforcement-Provisions.pdf

${ }^{4}$ Author's interview with Sherry Perreault, 20 April 2016. 
period for lobbyists to engage with legislation in January 2016, with generally good representation across a number of sectors expected to be lobbying. In welcoming these returns, Minister Howlin stressed that the legislation itself and these registrations and returns were not an end to themselves but a 'pathway to a culture change which recognises that transparent lobbying is essential to good policymaking. Over time I am confident that the lobbying register will continue to support and strengthen the information channels between the political system, the public service, and all sectors of society' (Department of Public Expenditure and Reform, 2016).

However, the Act is not without its weaknesses. The most significant difficulty is the absence of any trigger for registration based upon preparatory work and the giving of advice. This could potentially result in many commercial and in-house lobbyists being able to avoid registering. This would certainly defeat the purpose of the bill in ensuring transparency and accountability across the lobbying sector, and is something the government needs to consider in reviewing the Act. The other main weakness, which should be rectified, is the omission of any reference to financial information in the register, both initially and on the list of topics to which the register could be extended in the future. ${ }^{5}$ In the US and Canada, reference to financial information is commonplace and not seen as in any way private. Where private companies or interest groups pay lobbyists to lobby governments on their behalf, then it is certainly arguable that the sums of monies involved should be in the public domain. In launching the lobbying register in April 2015 Minister Howlin was at pains to say that the Regulation of Lobbying Act contained extensive and essential checks and balances to ensure that it 'doesn't have a "chilling" effect on lobbying activity. The information to be registered takes account of the need to minimise the administrative burden so not every meeting, phone call or email has to be listed individually. Rather the focus is on capturing the subject matter, the results intended to be achieved, who was contacted and the type and extent of the communications' (Howlin, 2015). This is all to be welcomed but it also seems reasonable that the public should know how much monies were expended in capturing the subject matter. If the government thought that this was

5 I am grateful to Dr Conor McGrath for sharing with me his own views of the Regulation of Lobbying Act. Dr McGrath made a very incisive contribution to the Act when he made a submission to the Department of Public Expenditure and Reform after the publication of the general lobbying scheme. It can be seen at http://www.per.gov.ie/wp-content/uploads/Conor-McGrath1.pdf 
a step too far in the Act's first iteration, as it clearly did given the groundbreaking nature of the Act, it could surely have indicated that this was something it would consider in future versions of the Act. This is something that governments should examine again in the future.

One issue that remains contentious is the so-called cooling-off period where former office holders or civil servants working in government should not be able to become lobbyists until a certain period of time has passed. In the programme for government Fine Gael and Labour promised to 'amend the rules to ensure that no senior public servant (including political appointees) or Minister can work in the private sector in any area involving a potential conflict of interest with their former area of public employment, until at least two years have elapsed after they have left the public service' (Department of the Taoiseach, 2011). Yet in the Act the restriction during which former public officials may not lobby their former colleagues (either in the public body where the new lobbyist once worked, or in the public body their former colleagues have since moved on to) stands at one year. This poses the question as to whether restrictions should apply across all lobbying activities rather than simply in the specific area of the person's former public employment. Moreover, it also brings into question the situation whereby people receive privileges by virtue of their former public employment, whether as TD or adviser, such as an access pass. There seems to be no adequate or even plausible reason as to why this remains the case and the question should surely be asked as to whether such privileges should be relinquished for at least the duration of an individual's lobbying career.

This issue came to light in March 2014 when it was revealed that former Fine Gael adviser Frank Flannery had spoken to then Minister for Education Ruairí Quinn, TD, about the activities of the charity Rehab, of which Flannery was a former CEO, director and consultant while also being a key strategist for Fine Gael. Quinn stated that Flannery would have spoken to him about concerns regarding state funding to Rehab for its lottery scheme 'but not in any kind of lobbying way'. Quinn made his remarks on the Today with Seán O'Rourke radio show on RTÉ Radio One and they were widely reported in the national newspapers. This begged the question of what exactly was lobbying. The Quinn-Flannery conversation took place at a time when the Rehab group was before the Dáil's Public Accounts Committee and essentially reinforced the need for Ireland to introduce lobbying regulations. The access available to Flannery was something that most interest groups and certainly citizens do not have. It is difficult to 
believe that speaking to a senior minister in the corridors of Leinster House about the activities of an organisation which could be significantly affected by government decisions could be anything but lobbying. Quinn, however, did not see it that way. In any event, the important point is that Flannery had such clear access to ministers who were making decisions that would have a significant impact on a charity group with which he was intimately involved.

While Frank Flannery was lobbying for Rehab, and getting paid for it, he was a key strategist for Fine Gael, the main government party. As director of elections for the then upcoming local elections in 2014 and director of organisation and strategy of the largest political party in the state, and one that led the government, he was in a unique position to be listened to by those he was lobbying even if the ministers, such as Quinn in this instance, were members of a different party. The two key aspects of lobbying activity in democratic societies are access to decision-makers, whether public representatives, civil servants or political advisers, and the expectation those lobbyists have as a result of that access. Flannery's access seemed unparalleled and served as a reminder of why lobbying should be regulated. While having quiet words in decision-makers' ears can never be truly legislated for, access certainly can be and should be, as this example makes patently clear.

The regulation of lobbyists in democratic societies allows citizens to openly see what lobby groups are doing and to whom in government they are talking, with the result that, over time, citizens become less cynical about the work and nature of lobbyists, and indeed politicians. It also tempers the unreasonable expectations that some lobbyists might have, given that their lobbying activities are available for public scrutiny. In essence, lobbying regulation exists so that the public can know who is lobbying who about what, as the government articulated in its ultimate Regulation of Lobbying Act.

Across the globe, lobbying regulations include a cooling-off period whereby those who serve as politicians, advisors or civil servants cannot immediately become lobbyists once they have left public office. It is an essential part of keeping citizens' trust in public life and ensuring that parliaments are not seen as cosy cartels for political insiders. These can range from one year to five years, as is the case in Washington State in the US. It is not clear why the government changed from its original two-year proposition to a one-year position. Given the fact that Ireland remains a relatively small polity with a peculiar electoral system, which fosters a form of localism unsurpassed 
in Western Europe, the government would probably have been better served going for a longer period between the time serving in a government administration and acting as a lobbyist, but this decision can be reviewed in time.

\section{Conclusion}

Lobbyists themselves clearly recognise that 'lobbying involves more than simply direct contact with policymakers, and that it does encompass information gathering and dissemination' (McGrath, 2011, p. 131). The Public Relations Institute of Ireland (PRII), the organisation which promotes the professional practice of public relations in Ireland, has been a supporter of lobbying regulation, seeing it as part of a wider trend in relation to openness and transparency not simply in Ireland but across the globe. In that context the PRII has worked closely with the Department of Public Expenditure and Reform and the Standards in Public Office Commission in relation to the Regulation of Lobbying Act to ensure that the legislation is implemented in as straightforward a manner as possible, and one which promotes compliance. Its chief executive, John Carroll, also sits on the Act's advisory group. In that context it seems clear that lobbyists themselves should be pleased with the legislation to which they have signed up. They work in a profession that is now not only regulated but has been given the imprimatur of government as one that, in the words of Minister Howlin, is important in supporting and strengthening 'the information channels between the political system, the public service, and all sectors of society' (Department of Public Expenditure and Reform, 2016).

But not everyone has been convinced by the regulation of lobbyists. The late P. J. Mara, former lobbyist and spin doctor for Fianna Fáil, described attempts to regulate lobbyists as 'bullshit', stating 'if that's what they want to do [the Coalition], away with them. But it's still not going to stop people having quiet words in corners. People are going to find their way around that, if they want to' (McEnroe, 2013).

So is this Act the ultimate fool's errand in supposedly ensuring transparency but in fact doing no such thing? In general, the evidence suggests that, rather than being a fool's errand, the Act was actually the government's finest hour in relation to ensuring openness in public life and has made Irish politics more transparent and accountable. While it could have certainly gone further in relation to the cooling-off period and the disclosure of financial information, the fact that the law 
does allow for citizens to know who is lobbying whom about what is a seismic step forward for a country which has been blighted for years by the perception that certain individuals and groups had greater access to and influence on the policymaking process to the detriment of wider society. Lobbying regulation clearly has benefits for politicians and policymakers, lobbyists and citizens. Policymakers can more easily determine which groups have lobbied on a particular issue and are thus in a better position to assess whether an equitable range of views have been taken into consideration during the policymaking process. Moreover, neither politicians nor civil servants are omniscient when it comes to policymaking and can clearly benefit from the knowledge and experience of interest groups and lobbyists when making a decision. The key point is that such lobbyists do not have undue influence. By ensuring that the activity of lobbyists is regulated, governments can reassure their citizens that policymaking is conducted in an open and legitimate manner free from any taint of corruption. This also benefits lobbyists. Internationally it is clear that lobbyists in regulated systems believe that lobbying regulations, and rules on spending disclosure, help ensure transparency and accountability (Murphy et al., 2011, p. 118).

Ultimately, the Regulation of Lobbying Act is built upon regulation introduced in North America, particularly Canada, which has stood the test of time. This is a classically good example of policy learning, showing the positive experience that the Irish state has gained from its examination of the international environment in order to produce better public policy. It is also a classic case of policy entrepreneurship at cabinet, where Minister Howlin was the driving force in ensuring the Act had sufficient strength to enable it to address the critical question of corrupt influence in public life. The Fine Gael/Labour government was aware that it could not simply replicate what had worked in other countries. Rather, it devised its own regulatory system, which was influenced by the international context. Given its importance as a piece of legislation which strengthens the power of the citizen to know what is happening in government, Irish citizens should welcome it as an important contribution towards guaranteeing that the state has the appropriate architecture to ensure openness, transparency and accountability in public life. 


\section{References}

Bitonti, A., \& Harris, P. (2017). An introduction to lobbying and public affairs. In A. Bitonti and P. Harris (Eds), Lobbying in Europe: Public affairs and the lobbying industry in 28 EU countries (pp. 1-16). Basingstoke: Palgrave.

Byrne, E. (2012). Political corruption in Ireland 1922-2010: A crooked harp? Manchester: Manchester University Press.

Chari, R., Hogan, J., \& Murphy, G. (2010). Regulating lobbying: A global comparison. Manchester: Manchester University Press.

Chari, R., Murphy, G., \& Hogan, J. (2007). Regulating lobbyists: A comparative analysis of the USA, Canada, Germany and the European Union. The Political Quarterly, 78 (3), 422-38.

Department of Public Expenditure and Reform. (2014). Minister Howlin announces publication of Registration of Lobbying Bill 2014 [press release]. Retrieved from http://www.per.gov.ie/en/minister-howlin-announcespublication-of-registration-of-lobbying-bill-2014/ [24 March 2017].

Department of Public Expenditure and Reform. (2016). Minister Howlin welcomes strong compliance with Regulation of Lobbying Act [press release]. Retrieved from http://www.per.gov.ie/en/strong-compliance-lobbying-act/ [24 March 2017].

Department of the Taoiseach. (2007). Programme for government 2007-2012. Retrieved from http://www.taoiseach.gov.ie/eng/Publications/Publications Archive/Publications_2007/Eng_Prog_for_Gov.pdf [20 March 2017].

Department of the Taoiseach. (2009). Renewed programme for government. Retrieved from http://www.taoiseach.gov.ie/eng/Publications/Publications 2009/Renewed_Programme_for_Government,_October_2009.pdf $\quad[2 \overline{0}$ March 2017].

Department of the Taoiseach. (2011). Programme for government, 2011-2016. Retrieved from http://www.taoiseach.gov.ie/eng/Work_Of_The_Depart ment/Programme_for_Government/Programme_for_Government_20112016.pdf [24 March 2017].

Dryzek, J. (2000). Democracy and beyond. Oxford: Oxford University Press.

Elster, J. (1998). Deliberative democracy. Cambridge: Cambridge University Press.

Fallon, J. (2011). Access: Insider perk or key to transparency. Journal of Public Affairs, 11 (2), 120-6.

Graziano, L. (2001). Lobbying, pluralism and democracy. London: Palgrave.

Hogan, J., \& Feeney, S. (2012). Crisis and policy change: The role of the political entrepreneur. Risk, Hazards \& Crisis in Public Policy, 3 (2), 1-24.

Howlin, B. (2015). Speech by Mr Brendan Howlin, TD, Minister for Public Expenditure and Reform at the launch of the lobbying register, 30 April 2015. Retrieved from http://www.per.gov.ie/en/speech-by-mr-brendan-howlin-td-at-the-launch-of-the-lobbying-register/ [27 March 2017].

Keohane, R. O., \& Nye, J. (2003). Redefining accountability for global governance. In M. Kahler \& D. Lake (Eds), Governance in a global 
economy: Political authority in transition (pp. 386-411). Princeton, NJ: Princeton University Press.

Lagerlof, J., \& Frisell, L. (2004). Lobbying, information transmission and unequal representation. Centre for Economic Policy Research, 4,313, 1-27.

MacCarthaigh, M., \& Martin, S. (2015). Bicameralism in the Republic of Ireland: The Seanad abolition referendum. Irish Political Studies, 30 (1), $121-31$.

McEnroe, J. (2013, August 26). PJ Mara: Banking inquiry would absolve Fianna Fáil of blame. Irish Examiner.

McGrath, C. (2009). The lobbyist with 'balls of iron and a spine of steel': Why Ireland needs lobbying reform. Journal of Public Affairs, 9, 256-71.

McGrath, C. (2011). Lobbying in Ireland: a reform agenda. Journal of Public Affairs, 11 (2), 127-34.

Murphy, G. (2010a). Interest groups in the policy-making process. In J. Coakley \& M. Gallagher (Eds), Politics in the Republic of Ireland (5th ed; pp. 327-58). Abingdon: Routledge.

Murphy, G. (2010b). Access and expectation: Interest groups in Ireland. In J. Hogan, P. F. Donnelly \& B. K. O'Rourke (Eds), Irish business and society: Governing, participating and transforming in the twentieth-first century (pp. 489-504). Dublin: Gill \& Macmillan.

Murphy, G. (2016). Electoral competition in Ireland since 1987: The politics of triumph and despair. Manchester: Manchester University Press.

Murphy, G. (2017). Ireland. In A. Bitonti \& P. Harris (Eds), Lobbying in Europe: Public affairs and the lobbying industry in $28 \mathrm{EU}$ countries (pp. 195-206). Basingstoke: Palgrave.

Murphy, G., Hogan, J., \& Chari, R. (2011). Lobbying regulation in Ireland: some thoughts from the international evidence. Journal of Public Affairs, 11 (2), 111-9.

Murphy, G., \& McGrath, C. (2011). The curious case of lobbying in Ireland. Journal of Public Affairs, 11 (2), 71-3.

Standards in Public Office Commission. (2015). Regulation of lobbying. Retrieved from http://www.sipo.gov.ie/Website/en/About-Us/Registrationof-Lobbying/ [24 March 2017].

Thomas, C. (2004). Lobbying in the United States: An overview for students, scholars and practitioners. In P. Harris \& C. S. Fleischer (Eds), The handbook of public affairs (pp. 281-303). London: Sage. 